\title{
Analisis Hubungan Dukungan Sosial dan Efikasi Diri dengan Perilaku Penggunaan Alat Pelindung Diri di PT. Pertamina (Persero) DPPU Juanda Sidoarjo
}

\author{
Relation Analysis of Social Support and Self-Efficacy with the Behavior of Using \\ Personal Protective Equipment at PT Pertamina (Persero) DPPU \\ Juanda Sidoarjo
}

\author{
Mahesa Arya Muharram \\ Fakultas Kesehatan Masyarakat, Universitas Airlangga, Surabaya, Indonesia \\ mahesamuharram@gmail.com \\ DOI: http://doi.org/10.29080/jhsp.v4i2.410 \\ Received: Juni 2020, Accepted : Juli 2020, Published : Agustus 2020
}

\begin{tabular}{l} 
Kata Kunci \\
\hline Dukungan Sosial, \\
Efikasi Diri, \\
APD
\end{tabular}

\section{Keywords}

Social Support Self-Efficacy,

$P P E$

\section{Abstrak}

Mengurangi risiko bagi pekerja dapat dilakukan dengan berbagai cara salah satunya dengan upaya pencegahan kecelakaan kerja yang dilakukan sesuai dengan hirarki pengendalian yang terdiri dari pengendalian teknik, pengendalian administratif, dan APD (Alat Pelindung Diri). Penelitian ini bertujuan untuk menganalisis hubungan antara dukungan sosial dan efikasi diri dengan perilaku penggunaan APD (Alat Pelindung Diri) pada pekerja fungsi RSD (receiving, storage, distribution) PT. Pertamina (Persero) DPPU Juanda Sidoarjo. Jenis penelitian ini adalah analitik observasional dengan pendekatan kuantitatif, dengan jumlah 71 sampel. Analisis data yang digunakan dalam penelitian ini adalah tabulasi silang dan regresi logistik ganda. Hasil dari penelitian ini menunjukkan bahwa pengetahuan, dukungan emosional, dukungan informasional, dukungan instrumental, efikasi tingkatan, efikasi keluasaan berhubungan dengan perilaku penggunaan APD. Sedangkan pengetahuan dan dukungan informasi menjadi variabel independen yang mempengaruhi perilaku penggunaan APD (Alat Pelindung Diri) dengan nilai Exp(B) sebesar 8,664 dan 18,682. Kesimpulan dari penelitian ini adalah faktor yang berhubungan dengan perilaku penggunaan APD (Alat Pelindung Diri) adalah pengetahuan, dukungan emosional, instrumental, informatif, efikasi tingkatan, efikasi keluasaan. Sedangkan pegetahuan dan dukungan informatif menjadi variabel yang mempengaruhi perilaku penggunaan APD (Alat Pelindung Diri).

\section{Abstract}

Reducing risks for workers can be done in various ways, one of which is by preventing work accidents in accordance with the hierarchy of controls consisting of technical controls, administrative controls, and personal protective equipment (PPE). This study aims to analyze the relationship between social support and self-efficacy with PPE (Personal Protective Equipment) usage behaviour in RSD (receiving, storage, distribution) worker functions of PT. Pertmaina (Persero) DPPU Juanda Sidoarjo. This type of research is observational analytic with a quantitative approach, with 71 samples. Analysis of the data used in this study was cross-tabulation and multiple logistic regression. The results of this study indicate that knowledge, emotional support, informational support, instrumental support, level of efficacy, the efficacy of freedom are related to PPE usage behaviour. While knowledge and information support become independent variables that influence the behaviour of PPE usage with Exp (B) values of 8,664 and 18,682. The conclusion of this study is that factors related to PPE use behaviour are knowledge, emotional support, instrumental, informative, level of efficacy, the efficacy of freedom. While knowledge and informative support are the variables that influence the behaviour of using PPE. 


\section{Pendahuluan}

Kebutuhan manusia pada era globalisasi seperti saat ini, mempengaruhi berbagai aspek dalam kehidupan, salah satunya kebutuhan transportasi. Transportasi merupakan salah satu mata rantai jaringan distribusi barang dan mobilitas penumpang yang berkembang sangat dinamis, serta berperan dalam mendukung, mendorong, dan menunjang segala aspek kehidupan baik dalam pembangunan politik, ekonomi, sosial budaya dan petahanan keamanan. Transportasi udara merupakan salah satu transportasi yang paling diminati oleh masyarakat Indonesia.

Sejalan dengan hal tersebut, peningkatan jadwal penerbangan juga berpengaruh terhadap peningkatan kebutuhan bahan bakar pesawat (avtur). Sehingga industri migas (minyak dan gas) mengalami peningkatan permintaan bahan bakar pesawat. Dampak yang ditimbulkan tidak hanya meningkatnya jumlah bahan bakar yang dibutuhkan, tetapi juga beban kerja yang dialami oleh pekerja. Pekerja mendapatkan beban kerja lebih karena dituntut untuk bekerja lebih cepat untuk memenuhi kebutuhan, hal itu juga dapat semakin meningkatkan risiko akan kecelakaan kerja.

Indonesia melalui BPJS Ketenagakerjaan mencatat setidaknya terdapat 98-100 ribu kasus setiap tahunnya dengan angkatan kerja sebanyak 121 juta tenaga kerja. Sedangkan gambaran distribusi kecelakaan kerja yang terakhir yakni berdasarkan data Kementerian Ketenagakerjaan pada tahun 2017 yang mencatat bahwa angka kecelakaan kerja di Indonesia adalah 80.393 kasus, yang tidak hanya terjadi di sektor formal namun juga di sektor informal.

Akibat yang ditimbulkan dari kecelakaan maupun penyakit akibat kerja tidak hanya merugikan pekerja namun juga merugikan perusahaan. Melalui bentuk pengeluaran lebih sebagai santunan atau biaya pengobatan. Diperkirakan jumlah yang diperlukan dalam pengeluaran biaya pengobatan dan pemulihan bagi para pekerja dari kesehatan dan keselamatan kerja yang buruk yakni mencapai 3,94\% dari Gross Domestic Product (GDP) global setiap tahun [1]. Hal ini selaras dengan teori kerugian kecelakaan kerja oleh [2] yakni kerugian akibat kecelakaan kerja digambarkan seperti gunung es. Permukaan yang muncul di atas hanya menggambarkan sebagian kecil dari kerugian atau disebut dengan direct costs seperti biaya pengobatan, biaya medis, santunan, dan lain-lain. Akan tetapi jumlah ini belum menggambarkan keseluruhan kerugian. Indirect cost sendiri berupa kerugian produksi, hilangnya jam kerja, hilangnya jumlah produksi, dan lain-lain [3].

Upaya keselamatan dan kesehatan kerja sudah sepatutnya harus benar-benar diterapkan dalam suatu perusahaan atau industri. Pelaksanaan dan pengawasannya juga tidak hanya berfokus pada faktor mesin saja namun juga harus pada pekerja itu sendiri. Hal ini dikarenakan mayoritas penyebab kecelakaan kerja berasal dari faktor manusia itu sendiri. Hal lain yang diperhatikan yaitu manusia merupakan sebuah aset bagi perusahaan dan faktor yang paling penting dalam suatu proses produksi. Manusia sebagai tenaga kerja merupakan pihak pertama yang akan selalu berhadapan langsung dengan risiko kerja yang bisa saja akan berdampak pada kecacatan fisik/fungsi atau bahkan sampai meninggal $[4]$.

Mengurangi risiko bagi pekerja dapat dilakukan dengan berbagai cara salah satunya dengan upaya pencegahan kecelakaan kerja yang dilakukan sesuai dengan hirarki pengendalian yang terdiri dari pengendalian teknik, pengendalian administratif, dan APD (Alat Pelindung Diri) [5]. APD (Alat Pelindung Diri) merupakan seperangkat alat keselamatan yang digunakan oleh pekerja untuk melindungi seluruh atau sebagian tubuh dari kemungkinan adanya papaaran potensi bahaya lingkungan kerja terhadap kecelakaan dan penyakit akibat kerja [6]. Cakupan dari alat pelindung diri meliputi semua pakaian dan aksesories pekerjaan lain yang dirancang sebagai penghalang terhadap sebuah kecelakaan pada tempat kerja. Menurut Peraturan Menteri Tenaga Kerja dan Transmigrasi nomor 08 tahun 2010 menjelaskan bahwa penyediaan APD (Alat Pelindung Diri) pada pekerja oleh perusahaan atau industri wajib dilaskanakan.

Penelitian oleh Heinrich dalam [7] menyebutkan bahwa kecelakaan kerja 88\% disebabkan oleh unsafe action. Salah satu bentuk tindakan tidak aman ini adalah penggunaan APD (Alat Pelindung Diri) yang tidak sesuai dengan standar yang berlaku [8]. Hal tersebut dapat dipengaruhi oleh perilaku pekerja itu sendiri yang tidak bekerja sesuai dengan prosedur. Perilaku tersebut dapat dilihat dari penggunaan APD (Alat Pelindung Diri) saat bekerja. Berdasarkan teori dukungan sosial yang dinyatakan oleh [9] dijelaskan bahwa, terjadinya perilaku karena adanya dukungan dari lingkungan sekitar mencakup teman, keluarga, rekan kerja, dan perusahaan dalam bentuk memberi nasihat, perhatian, informasi, bantuan barang jasa, dan penghargaan. Dukungan sosial dari lingkungan sekitar ini lah yang dapat mempengaruhi seseorang dalam melakukan perubahan perilaku dalam hal ini ialah penggunaan APD (Alat Pelindung Diri) sesuai prosedur perusahaan. Selain itu terjadinya perilaku individu juga dapat dipengaruhi oleh efikasi diri/kemampuan diri. Efikasi diri merupakan kemampuan diri untuk menjalankan tugas/mengatasi masalah yang sedang dihadapi.

Tujuan penelitian ini adalah untuk mengetahui secara pasti hubungan dukungan sosial dan efikasi diri dalam mendorong perilaku pekerja dalam penggunaan APD (Alat Pelindung Diri) pada pekerja di fungsi RSD (Recieving, Storage, Distribution). Sehingga dapat digunakan PT. Pertamina (Persero) DPPU 
Juanda Sidoarjo dalam menentukan upaya perbaikan dan keberlanjutan program K3 khususnya mengenai perilaku penggunaan APD (Alat Pelindung Diri) pada lingkungan kerja.

\section{Metode Penelitian}

Penelitian yang dilakukan merupakan jenis observasional analitik dengan pendekatan kuantitatif serta menggunakan desain cross sectional. Observasional analitik yaitu suatu penelitian yang menentukan adanya hubungan antara satu variabel dengan variabel lainnya dengan pendekatan kuantitatif. Peneliti cross sectional yaitu pengumpulan data yang dilakukan sekaligus pada waktu tertentu. Lokasi penelitian ini berada di PT. Pertamina (Persero) DPPU Juanda, Sedati, Sidoarjo, Jawa Timur dengan waktu penelitian dimulai pada bulan Juli - Agustus 2019.

Populasi penelitian adalah pekerja di fungsi RSD (Recieving, Storage, Distribution) di PT. Pertamina (Persero) DPPU Juanda yang berjumlah 85 pekerja. Berdasarkan jumlah populasi tersebut ditentukan sampel sebanyak 71 orang menggunakan metode simple random sampling yang diambil secara acak pada pekerja fungsi RSD (Recieving, Storage, Distribution) sebanyak 85 pekerja karena memiliki jenis pekerjaan yang sama dan tanpa melihat tingkatan yang ada dalam populasi. Cara perhitungan menggunakan rumus Slovin dengan taraf signifikansi $5 \%(\alpha=0,05)$. Terdapat kriteria yang diberlakukan pada pekerja yakni pekerja harus berasal dari fungsi RSD (Recieving, Storage, Distribution), serta bersedia, menyetujui, dan untuk dilibatkan sebagai responden dalam masa penelitian hingga selesai.

Teknik pengumpulan data dalam penelitian ini menggunakan dua sumber data, yaitu data primer dan data sekunder. Data primer meliputi, pengumpulan data primer dilakukan menggunakan pertanyaan dari kuesioner dan melakukan obervasi perilaku penggunaan APD (Alat Pelindung Diri). Pengumpulan data dimulai dengan peneliti menjelaskan tujuan dan manfaat keterlibatan dalam penelitiian. Kemudian meminta ketersediaan responden untuk mengikuti penelitian dengan melakukan pengisian inform concent, dilanjutkan dengan responden menjawab pertanyaan dengan mengisi kuesioner. Pengisian kuesioner dilakukan sekitar 15 menit yang dilaksanakan di fungsi RSD PT. Pertamina (Persero) DPPU Juanda. Observasi perilaku penggunaan APD (Alat Pelindung Diri) dilakukan dengan melakukan pengisian lembar checklist yang dilakukan oleh peneliti yang dilaksanakan sebelum bekerja dan saat jam istirahat. Sedangkan data sekunder merupakan data yang diambil dari data perusahaan dan studi literatur yang mendukung penelitian.

Terdapat dua variabel dalam penelitian ini, yang pertama yaitu variabel bebas yang dilihat dari aspek karakteristik responden, dukungan sosial (dukungan emosional, dukungan informatif, dukungan instrumental, dan dukungan penghargaan), dan efikasi diri (tingkatan, keluasaan, dan kekuatan). Sedangkan terdapat variabel terikat yaitu perilaku penggunaan APD (Alat Pelindung Diri) oleh pekerja di fungsi RSD PT. Pertamina (Persero) DPPU Juanda. Analisa data menggunakan tabulasi silang dengan melihat kuat hubungan antara masing-masing variabel bebas yang dihubungkan dengan variabel terikat. Kuat hubungan tersebut muncul saat dilakukannya proses analisis data menggunakan metode Chi Square.

\section{Hasil Penelitian}

Riset yang telah dilakukan pada 71 responden maka diketahui distribusi Umur, Pendidikan Terakhir, Masa Kerja, dan Pengetahuan sebagaimana terlihat di Tabel 1.

Tabel 1. Distribusi Frekuensi Responden Berdasarkan Umur, Pendidikan Terakhir, Masa Kerja, dan Pengetahuan di Fungsi RSD (Receiving, Storage, Distribution) PT. Pertamina (DPPU) Juanda Sidoarjo 18 September 2019

\begin{tabular}{lcc}
\hline Variabel & Jumlah & Persentase (\%) \\
\hline Usia & & \\
19-24 Tahun & 8 & 11.3 \\
25-34 Tahun & 31 & 43.7 \\
35-44 Tahun & 21 & 29.5 \\
$\quad$ 45-54 Tahun & 11 & 15.5 \\
\hline Total & 71 & 100 \\
\hline Pendidikan & & \\
$\quad$ SMA & 53 & 74.6 \\
$\quad$ D3/D4/Sarjana & 18 & 25.4 \\
\hline Total & 71 & 100 \\
\hline Masa Kerja & & \\
$\quad<6$ Tahun & 17 & 24 \\
6-10 Tahun & 28 & 39.4 \\
$\quad>10$ Tahun & 26 & 36.6 \\
\hline Total & 71 & 100 \\
\hline Pengetahuan & & \\
$\quad$ Baik & 59 & 83.1 \\
$\quad$ Sedang & 12 & 16.9 \\
\hline Total & 71 & 100 \\
\hline
\end{tabular}


Berdasarkan Tabel 1 diketahui hasil penelitian dari 71 orang responden di fungsi RSD Usia mayoritas responden berusia 25-34 tahun dengan jumlah sebanyak 31 pekerja (43.7\%), sebanyak 21 pekerja (29.6\%) dengan usia 35-44 tahun, sebanyak 11 pekerja (15.5\%) dengan usia 45-54 tahun, dan sebanyak 8 pekerja (11.3\%) dengan usia 19-24 tahun.

Variabel pendidikan terakhir berdasarkan Tabel 1 hasilnya mayoritas pekerja adalah SMA dengan jumlah 53 pekerja (74.6\%), dan D3/D4/S1 sebanyak 18 pekerja (25.6\%). Kemudian, Hasil penelitian dari 71 orang responden di fungsi RSD berdasarkan Tabel 1 diketahui bahwa masa kerja mayoritas pekerja yaitu 6-10 tahun dengan jumlah 28 pekerja (39.4\%).

Berdasarkan Tabel 1 menunjukkan bahwa mayoritas pengetahuan pekerja di fungsi RSD (recieving, storage, distribution) mengenai jenis dan fungsi APD (Alat Pelindung Diri) sudah baik. Pertanyaan pengetahuan APD (Alat Pelindung Diri) kepada responden yaitu mengenai pengertian dari APD (Alat Pelindung Diri), fungsi dari penggunaan APD (Alat Pelindung Diri), letak penggunaan APD (Alat Pelindung Diri), cara penggunaan APD (Alat Pelindung Diri), dan jenis letak APD (Alat Pelindung Diri) yang digunakan.

Sedangkan untuk Dukungan Sosial dalam penggunaan APD (Alat Pelindung Diri) di fungsi RSD (Receiving, Storage, Distribution) PT. Pertamina (DPPU) Juanda Sidoarjo juga sudah berjalan melalui adanya pemberian perhatian, nasihat, bantuan, dan penghargaan dari keluarga, rekan kerja, dan perusahaan terhadap perilaku penggunaan APD (Alat Pelindung Diri). Sementara itu, untuk data Distribusi Frekuensi Dukungan Emosional, Dukungan Informatif, Dukungan Instrumental, dan Dukungan Penghargaan di fungsi RSD (Receiving, Storage, Distribution) PT. Pertamina (DPPU) Juanda Sidoarjo dapat ditampilkan sebagaimana terlihat di Tabel 2.

Tabel 2. Distribusi Frekuensi Dukungan Emosional, Dukungan Informatif, Dukungan Instrumental, dan Dukungan Penghargaan di fungsi RSD (Receiving, Storage, Distribution) PT. Pertamina (DPPU) Juanda Sidoarjo 18 September 2019

\begin{tabular}{lcc}
\hline Variabel & Jumlah & Persentase (\%) \\
\hline Dukungan Emosional & & \\
$\quad$ Tinggi & 58 & 81.7 \\
$\quad 13$ & 18.3 \\
\hline Sedang & 71 & 100 \\
\hline Dukungan Informatif & & \\
$\quad$ Tinggi & 44 & 62 \\
$\quad$ Sedang & 27 & 38 \\
\hline Total & 71 & 100 \\
\hline Dukungan Instrumental & & 38 \\
$\quad$ Tinggi & 27 & 62 \\
$\quad$ Sedang & 44 & 100 \\
\hline Total & 71 & 40.8 \\
Dukungan Penghargaan & & 36.6 \\
$\quad$ Tinggi & 29 & 22.5 \\
$\quad$ Sedang & 26 & 100 \\
\hline Rendah & 16 & \\
\hline
\end{tabular}

Berdasarkan Tabel 2 distribusi frekuensi mengenai dukungan sosial diketahui bahwa mayoritas pekerja menerima dukungan emosional yang tinggi. Dukungan emosional berkaitan dengan perilaku penggunaan APD (Alat Pelindung Diri) yaitu mengenai pemberian perhatian, nasihat, saran, pengingat, dan teguran dari keluarga, rekan kerja, dan perusahaan kepada pekerja.

Hasil dari Tabel 2 menunjukkan distribusi frekuensi mengenai dukungan informatif diketahui bahwa mayoritas pekerja menerima dukungan informatif yang tinggi. Dukungan emosional berkaitan dengan perilaku penggunaan APD (Alat Pelindung Diri) yaitu mengenai pemberian informasi, pengarahan, dan bertukar informasi dari keluarga, rekan kerja, dan perusahaan kepada pekerja.

Tabel 2 juga menunjukkan distribusi frekuensi mengenai dukungan instrumental diketahui bahwa mayoritas pekerja menerima dukungan instrumental yang tinggi. Dukungan instrumental berkaitan dengan perilaku penggunaan APD (Alat Pelindung Diri) yaitu mengenai adanya bantuan dan tindakan langsung berupa pengawasan, perawatan, penggantian, dan secara finansial pada penggunaan APD (Alat Pelindung Diri) dari keluarga, rekan kerja, dan perusahaan kepada pekerja.

Selanjutnya Tabel 2 juga menunjukkan distribusi frekuensi mengenai dukungan penghargaan diketahui bahwa mayoritas pekerja menerima dukungan penghargaan yang tinggi. Pertanyaan mengenai dukungan penghargaan berkaitan dengan perilaku penggunaan APD (Alat Pelindung Diri) yaitu mengenai pemberian apresiasi, evaluasi, dan hadiah/tunjangan dari keluarga, rekan kerja, dan perusahaan kepada pekerja.

Sedangkan untuk data Distribusi Frekuensi Dukungan Efikasi Tingkatan, Dukungan Efikasi 
Keluasaan, Dukungan Efikasi Kekuatan, dan Perilaku Penggunaan APD (Alat Pelindung Diri) di fungsi RSD (Receiving, Storage, Distribution) PT. Pertamina (DPPU) Juanda Sidoarjo ditampilkan sebagaimana terlihat di Tabel 3.

Tabel 3. Distribusi Frekuensi Dukungan Efikasi Tingkatan, Dukungan Efikasi Keluasaan, Dukungan Efikasi Kekuatan, dan Perilaku Penggunaan APD (Alat Pelindung Diri) di fungsi RSD (Receiving, Storage, Distribution) PT. Pertamina (DPPU) Juanda Sidoarjo 18 September 2019

\begin{tabular}{lcc}
\hline Variabel & Jumlah & Persentase (\%) \\
\hline Efikasi Tingkatan & 62 & 87.3 \\
Tinggi & 9 & 12.7 \\
Sedang & 71 & 100 \\
\hline Total & & \\
\hline Efikasi Keluasaan & 44 & 62 \\
$\quad$ Tinggi & 27 & 38 \\
$\quad$ Sedang & 71 & 100 \\
\hline Total & & \\
\hline Efikasi Kekuatan & 51 & 71.8 \\
$\quad$ Tinggi & 20 & 28.2 \\
$\quad$ Sedang & 71 & 100 \\
\hline Total & & \\
\hline Perilaku Penggunaan APD & 51 & 71.8 \\
$\quad$ Tinggi & 20 & 28.2 \\
$\quad$ Sedang & $\mathbf{7 1}$ & $\mathbf{1 0 0}$ \\
\hline Total & & \\
\hline
\end{tabular}

Berdasarkan Tabel 3 diatas menunjukkan distribusi frekuensi mengenai efikasi tingkatan pada pekerja diketahui bahwa mayoritas efikasi tingkatan tinggi yakni 62/71 (87.3\%). Pertanyaan mengenai efikasi tingkatan terkait perilaku penggunaan APD (Alat Pelindung Diri) yaitu mengenai keyakinan responden untuk mampu menggunakan dan menerapkan perilaku penggunaan APD (Alat Pelindung Diri) dalam sesuai dengan tempat dan resiko kecelakaan yang ditimbulkan.

Hasil Tabel 3 diketahui bahwa distribusi frekuensi mengenai efikasi keluasaan pada pekerja mayoritas memiliki efikasi keluasaan tinggi. Efikasi keluasaan berkaitan dengan perilaku penggunaan APD (Alat Pelindung Diri) yaitu mengenai keyakinan dan kemampuan responden untuk menganggap bahwa perilaku penggunaan APD (Alat Pelindung Diri) merupakan kegaitan yang umum dilakukan oleh setiap pekerja.

Tabel 3 menunjukkan hasil distribusi frekuensi mengenai efikasi kekuatan pada pekerja diketahui bahwa mayoritas memiliki efikasi kekuatan tinggi. Efikasi kekuatan berkaitan dengan perilaku penggunaan APD (Alat Pelindung Diri) yaitu mengenai keyakinan dan kemampuan responden untuk mengikuti segala peraturan dan anjuran mengenai perilaku penggunaan APD (Alat Pelindung Diri) di lingkungan fungsi RSD (receiving, storage, distribution).

Berdasarkan Tabel 3 tentang hasil distribusi frekuensi mengenai perilaku penggunaan APD (Alat Pelindung Diri) pada pekerja diketahui bahwa mayoritas perilaku penggunaan APD (Alat Pelindung Diri) adalah baik. Observasi perilaku penggunaan APD (Alat Pelindung Diri) menggunakan lembar observasi yang dinilai oleh peneliti yang terdiri dari 7 kelengkapan APD (Alat Pelindung Diri) yang harus digunakan di fungsi RSD (recieving, storage, distribution) dan dibagi menjadi 2 sesi, yaitu awal sebelum bekerja dan setelah jam istirahat. Adapun kelengkapan APD (Alat Pelindung Diri) meliputi helm/topi safety, earplug/earmuff, safety vest/wear pack, safety shoes, safety gloves, mengencangkan tali strap, dan UV glasses.

\section{Hubungan Karakteristik Responden dengan Perilaku Penggunaan APD (Alat Pelindung Diri)}

Hasil tabulasi silang antara umur dengan perilaku penggunana APD (Alat Pelindung Diri) pada pekerja di fungsi RSD (recieving, storage, distribution), diperoleh data sebagai berikut:

Tabel 4. Tabulasi Silang Umur dengan Perilaku Penggunaan APD (Alat Pelindung Diri) di fungsi RSD (Receiving, Storage, Distribution) PT. Pertamina (DPPU) Juanda Sidoarjo 18 September 2019

\begin{tabular}{|c|c|c|c|c|c|c|c|}
\hline \multirow{3}{*}{ Umur } & \multicolumn{4}{|c|}{ Perilaku Penggunaan APD (Alat Pelindung Diri) } & \multirow{2}{*}{\multicolumn{2}{|c|}{ Persentase (\%) }} & \multirow[b]{2}{*}{$\boldsymbol{P}$} \\
\hline & \multicolumn{2}{|c|}{ Baik } & \multicolumn{2}{|c|}{ Cukup } & & & \\
\hline & $\mathrm{n}$ & $\%$ & $\mathrm{n}$ & $\%$ & $\mathrm{n}$ & $\%$ & \multirow{6}{*}{0.318} \\
\hline 15-24 tahun & 6 & 75 & 2 & 25 & 8 & 100 & \\
\hline 25-34 tahun & 25 & 80.6 & 6 & 19.4 & 31 & 100 & \\
\hline 35-44 tahun & 12 & 57.1 & 9 & 42.9 & 21 & 100 & \\
\hline 45-54 tahun & 8 & 72.7 & 3 & 27.3 & 11 & 100 & \\
\hline Total & 51 & 71.8 & 20 & 28.2 & 71 & 100 & \\
\hline
\end{tabular}


Berdasarkan Tabel 4 dapat diketahui bahwa pekerja dengan mayoritas umur 25-34 memiliki perilaku penggunaan APD (Alat Pelindung Diri) yang cenderung baik. Hasil uji tabulasi silang menjelaskan bahwa tidak terdapat hubungan yang bermakna antara umur dengan perilaku penggunaan APD (Alat Pelindung Diri).

Sedangkan untuk data Tabulasi Silang Pendidikan dengan Perilaku Penggunaan APD (Alat Pelindung Diri) di fungsi RSD (Receiving, Storage, Distribution) PT. Pertamina (DPPU) Juanda Sidoarjo dapat ditampilkan sebagaimana terlihat di Tabel 5.

Tabel 5. Tabulasi Silang Pendidikan dengan Perilaku Penggunaan APD (Alat Pelindung Diri) di fungsi RSD (Receiving, Storage, Distribution) PT. Pertamina (DPPU) Juanda Sidoarjo 18 September 2019

\begin{tabular}{|c|c|c|c|c|c|c|c|}
\hline \multirow{3}{*}{ Umur } & \multicolumn{4}{|c|}{ Perilaku Penggunaan APD (Alat Pelindung Diri) } & \multirow{2}{*}{\multicolumn{2}{|c|}{ Persentase (\%) }} & \multirow{2}{*}{$\boldsymbol{P}$} \\
\hline & \multicolumn{2}{|c|}{ Baik } & \multicolumn{2}{|c|}{ Cukup } & & & \\
\hline & $\mathrm{N}$ & $\%$ & $\mathrm{n}$ & $\%$ & $\mathrm{n}$ & $\%$ & \multirow{4}{*}{0.573} \\
\hline SMA & 39 & 73.6 & 14 & 26.4 & 53 & 100 & \\
\hline D3/D4/Sarjana & 12 & 66.7 & 6 & 33.3 & 18 & 100 & \\
\hline Total & 51 & 71.8 & 20 & 28.2 & 71 & 100 & \\
\hline
\end{tabular}

Berdasarkan Tabel 5 dapat diketahui pekerja dengan tingkat pendidikan minimal SMA, memiliki perilaku penggunaan APD (Alat Pelindung Diri) yang cenderung baik. Hasil uji tabulasi silang diketahui bahwa tidak ada hubungan yang bermakna antara pendidikan terakhir dengan perilaku penggunaan APD (Alat Pelindung Diri).

Sedangkan untuk data Tabulasi Silang Masa Kerja dengan Perilaku Penggunaan APD (Alat Pelindung Diri) di fungsi RSD (Receiving, Storage, Distribution) PT. Pertamina (DPPU) Juanda Sidoarjo dapat ditampilkan sebagaimana terlihat di Tabel 6.

Tabel 6. Tabulasi Silang Masa Kerja dengan Perilaku Penggunaan APD (Alat Pelindung Diri) di fungsi RSD (Receiving, Storage, Distribution) PT. Pertamina (DPPU) Juanda Sidoarjo 18 September 2019

\begin{tabular}{|c|c|c|c|c|c|c|c|}
\hline \multirow{3}{*}{ Masa Kerja } & \multicolumn{4}{|c|}{ Perilaku Penggunaan APD (Alat Pelindung Diri) } & \multirow{2}{*}{\multicolumn{2}{|c|}{ Persentase (\%) }} & \multirow{2}{*}{$\boldsymbol{P}$} \\
\hline & \multicolumn{2}{|c|}{ Baik } & \multicolumn{2}{|c|}{ Cukup } & & & \\
\hline & $\mathbf{n}$ & $\%$ & $\mathbf{n}$ & $\%$ & $\mathbf{n}$ & $\%$ & \\
\hline$<6$ tahun & 12 & 70.6 & 5 & 29.4 & 17 & 100 & \\
\hline 6-10 tahun & 22 & 78.6 & 6 & 21.4 & 28 & 100 & 0.596 \\
\hline$>10$ tahun & 17 & 65.4 & 9 & 34.6 & 26 & 100 & \\
\hline Total & 51 & 71.8 & 20 & 28.2 & 71 & 100 & \\
\hline
\end{tabular}

Berdasarkan Tabel 6 dapat diketahui pekerja dengan masa kerja >6 tahun, memiliki perilaku penggunaan APD (Alat Pelindung Diri) yang cenderung baik. Hasil uji tabulasi silang menjelaskan bahwa tidak ada hubungan yang bermakna antara masa kerja dengan perilaku penggunaan APD (Alat Pelindung Diri).

Sedangkan untuk data Tabulasi Silang Pengetahuan dengan Perilaku Penggunaan APD (Alat Pelindung Diri) di fungsi RSD (Receiving, Storage, Distribution) PT. Pertamina (DPPU) Juanda Sidoarjo dapat ditampilkan sebagaimana terlihat di Tabel 7.

Tabel 7. Tabulasi Silang Masa Kerja dengan Perilaku Penggunaan APD (Alat Pelindung Diri) di fungsi RSD (Receiving, Storage, Distribution) PT. Pertamina (DPPU) Juanda Sidoarjo 18 September 2019

\begin{tabular}{|c|c|c|c|c|c|c|c|}
\hline \multirow{3}{*}{ Pengetahuan } & \multicolumn{4}{|c|}{ Perilaku Penggunaan APD (Alat Pelindung Diri) } & \multirow{2}{*}{\multicolumn{2}{|c|}{ Persentase (\%) }} & \multirow{2}{*}{$\boldsymbol{P}$} \\
\hline & \multicolumn{2}{|c|}{ Baik } & \multicolumn{2}{|c|}{ Cukup } & & & \\
\hline & $\mathbf{n}$ & $\%$ & $\mathbf{n}$ & $\%$ & $\mathbf{n}$ & $\%$ & \multirow{4}{*}{0.000} \\
\hline Tinggi & 48 & 81.4 & 11 & 18.6 & 59 & 100 & \\
\hline Sedang & 3 & 25 & 9 & 75 & 12 & 100 & \\
\hline Total & 51 & 71.8 & 20 & 28.2 & 71 & 100 & \\
\hline
\end{tabular}

Berdasarkan Tabel 7 dapat diketahui bahwa pekerja dengan pengetahuan yang tinggi, memiliki perilaku penggunaan APD (Alat Pelindung Diri) yang cenderung baik. Hasil uji tabulasi silang menjelaskan bahwa terdapat hubungan yang siginifikan antara pengetahuan dengan perilaku penggunaan APD (Alat Pelindung Diri).

Sedangkan untuk data Tabulasi Silang Dukungan Emosional dengan Perilaku Penggunaan APD (Alat Pelindung Diri) di fungsi RSD (Receiving, Storage, Distribution) PT. Pertamina (DPPU) Juanda Sidoarjo dapat ditampilkan sebagaimana terlihat di Tabel 8. 
Tabel 8. Tabulasi Silang Dukungan Emosional dengan Perilaku Penggunaan APD (Alat Pelindung Diri) di fungsi RSD (Receiving, Storage, Distribution) PT. Pertamina (DPPU) Juanda Sidoarjo 18 September 2019

\begin{tabular}{lcccccccc}
\hline \multirow{2}{*}{$\begin{array}{l}\text { Dukungan } \\
\text { Emosional }\end{array}$} & \multicolumn{3}{c}{ Perilaku Penggunaan APD (Alat Pelindung Diri) } & \multicolumn{2}{c}{ Persentase (\%) } & \multirow{2}{*}{$\boldsymbol{P}$} \\
\cline { 2 - 5 } & $\mathbf{n}$ & $\mathbf{0}$ & $\mathbf{n}$ & $\mathbf{0}$ & $\mathbf{n}$ & $\mathbf{\%}$ \\
\hline Tinggi & 46 & 79.3 & 12 & 20.7 & 58 & 100 & \multirow{2}{*}{0.006} \\
Sedang & 5 & 38.5 & 8 & 61.5 & 13 & 100 & \\
\hline Total & $\mathbf{5 1}$ & $\mathbf{7 1 . 8}$ & $\mathbf{2 0}$ & $\mathbf{2 8 . 2}$ & $\mathbf{7 1}$ & $\mathbf{1 0 0}$ \\
\hline
\end{tabular}

Berdasarkan Tabel 8 dapat diketahui bahwa pekerja dengan dukungan emosional yang tinggi, memiliki perilaku penggunaan APD (Alat Pelindung Diri) yang cenderung baik. Hasil uji tabulasi silang menjelaskan terdapat hubungan yang siginifikan antara dukungan emosional dengan perilaku penggunaan APD (Alat Pelindung Diri).

Sedangkan untuk data Tabulasi Silang Dukungan Informatif dengan Perilaku Penggunaan APD (Alat Pelindung Diri) di fungsi RSD (Receiving, Storage, Distribution) PT. Pertamina (DPPU) Juanda Sidoarjo dapat ditampilkan sebagaimana terlihat di Tabel 9.

Tabel 9. Tabulasi Silang Dukungan Informatif dengan Perilaku Penggunaan APD (Alat Pelindung Diri) di fungsi RSD (Receiving, Storage, Distribution) PT. Pertamina (DPPU) Juanda Sidoarjo 18 September 2019

\begin{tabular}{lcccccccc}
\hline \multirow{2}{*}{$\begin{array}{l}\text { Dukungan } \\
\text { Informatif }\end{array}$} & \multicolumn{3}{c}{ Perilaku Penggunaan APD (Alat Pelindung Diri) } & & \multirow{2}{*}{ Persentase (\%) } & \multirow{2}{*}{$\boldsymbol{P}$} \\
\cline { 2 - 6 } & $\mathbf{n}$ & $\mathbf{\%}$ & $\mathbf{n}$ & $\mathbf{\%}$ & $\mathbf{n}$ & $\mathbf{\%}$ \\
\hline Tinggi & 41 & 93.2 & 3 & 6.8 & 4 & 100 & \multirow{2}{*}{0.000} \\
Sedang & 10 & 37 & 17 & 63 & 27 & 100 & $\mathbf{7 1}$ \\
\hline Total & $\mathbf{5 1}$ & $\mathbf{7 1 . 8}$ & $\mathbf{2 0}$ & $\mathbf{2 8 . 2}$ & $\mathbf{1 0 0}$ \\
\hline
\end{tabular}

Berdasarkan Tabel 9 dapat diketahui bahwa pekerja dengan dukungan informatif yang tinggi, memiliki perilaku penggunaan APD (Alat Pelindung Diri) yang cenderung baik. Hasil uji tabulasi silang menjelaskan terdapat hubungan yang siginifikan antara dukungan informatif dengan perilaku penggunaan APD (Alat Pelindung Diri).

Sedangkan untuk data Tabulasi Silang Dukungan Instrumental dengan Perilaku Penggunaan APD (Alat Pelindung Diri) di fungsi RSD (Receiving, Storage, Distribution) PT. Pertamina (DPPU) Juanda Sidoarjo dapat ditampilkan sebagaimana terlihat di Tabel 10.

Tabel 10. Tabulasi Silang Dukungan Instrumental dengan Perilaku Penggunaan APD (Alat Pelindung Diri) di fungsi RSD (Receiving, Storage, Distribution) PT. Pertamina (DPPU) Juanda Sidoarjo 18 September 2019

\begin{tabular}{|c|c|c|c|c|c|c|c|}
\hline \multirow{3}{*}{$\begin{array}{l}\text { Dukungan } \\
\text { Instrumental }\end{array}$} & \multicolumn{4}{|c|}{ Perilaku Penggunaan APD (Alat Pelindung Diri) } & \multirow{2}{*}{\multicolumn{2}{|c|}{ Persentase (\%) }} & \multirow{2}{*}{$\boldsymbol{P}$} \\
\hline & \multicolumn{2}{|c|}{ Baik } & \multicolumn{2}{|c|}{ Cukup } & & & \\
\hline & $\mathbf{n}$ & $\%$ & $\mathbf{n}$ & $\%$ & $\mathbf{n}$ & $\%$ & \multirow{4}{*}{0.050} \\
\hline Tinggi & 23 & 85.2 & 4 & 14.8 & 27 & 100 & \\
\hline Sedang & 28 & 63.6 & 16 & 36.4 & 44 & 100 & \\
\hline Total & 51 & 71.8 & 20 & 28.2 & 71 & 100 & \\
\hline
\end{tabular}

Berdasarkan Tabel 10 dapat diketahui pekerja dengan dukungan instrumental yang tinggi, memiliki perilaku penggunaan APD (Alat Pelindung Diri) yang cenderung baik. Hasil uji tabulasi silang menjelaskan terdapat hubungan yang siginifikan antara dukungan instrumental dengan perilaku penggunaan APD (Alat Pelindung Diri).

Sedangkan untuk data Tabulasi Silang Dukungan Instrumental dengan Perilaku Penggunaan APD (Alat Pelindung Diri) di fungsi RSD (Receiving, Storage, Distribution) PT. Pertamina (DPPU) Juanda Sidoarjo dapat ditampilkan sebagaimana terlihat di Tabel 11. 
Tabel 11. Tabulasi Silang Dukungan Penghargaan dengan Perilaku Penggunaan APD (Alat Pelindung Diri) di fungsi RSD (Receiving, Storage, Distribution) PT. Pertamina (DPPU) Juanda Sidoarjo 18 September 2019

\begin{tabular}{|c|c|c|c|c|c|c|c|}
\hline \multirow{3}{*}{$\begin{array}{l}\text { Dukungan } \\
\text { Penghargaan }\end{array}$} & \multicolumn{4}{|c|}{ Perilaku Penggunaan APD (Alat Pelindung Diri) } & \multirow{2}{*}{\multicolumn{2}{|c|}{ Persentase (\%) }} & \multirow{2}{*}{$\boldsymbol{P}$} \\
\hline & \multicolumn{2}{|c|}{ Baik } & \multicolumn{2}{|c|}{ Cukup } & & & \\
\hline & $\mathrm{n}$ & $\%$ & $\mathrm{n}$ & $\%$ & $\mathrm{n}$ & $\%$ & \\
\hline Tinggi & 24 & 82.8 & 5 & 17.2 & 29 & 100 & \\
\hline Sedang & 18 & 69.2 & 8 & 30.8 & 26 & 100 & 0.157 \\
\hline Rendah & 9 & 56.3 & 7 & 43.8 & 16 & 100 & \\
\hline Total & 51 & 71.8 & 20 & 28.2 & 71 & 100 & \\
\hline
\end{tabular}

Berdasarkan Tabel 11 dapat diketahui bahwa semakin tinggi dukungan penghargaan yang diterima, menimbulkan perilaku penggunaan APD (Alat Pelindung Diri) yang cenderung baik. Hasil uji tabulasi silang menjelaskan tidak terdapat hubungan yang bermakna antara dukungan penghargaan dengan perilaku penggunaan APD (Alat Pelindung Diri).

Sedangkan untuk data Tabulasi Silang Efikasi Tingkatan dengan Perilaku Penggunaan APD (Alat Pelindung Diri) di fungsi RSD (Receiving, Storage, Distribution) PT. Pertamina (DPPU) Juanda Sidoarjo dapat ditampilkan sebagaimana terlihat di Tabel 12.

Tabel 12. Tabulasi Silang Efikasi Tingkatan dengan Perilaku Penggunaan APD (Alat Pelindung Diri) di fungsi RSD (Receiving, Storage, Distribution) PT. Pertamina (DPPU) Juanda Sidoarjo 18 September 2019

\begin{tabular}{|c|c|c|c|c|c|c|c|}
\hline \multirow{3}{*}{$\begin{array}{l}\text { Efikasi } \\
\text { Tingkatan }\end{array}$} & \multicolumn{4}{|c|}{ Perilaku Penggunaan APD (Alat Pelindung Diri) } & \multirow{2}{*}{\multicolumn{2}{|c|}{ Persentase (\%) }} & \multirow{2}{*}{$P$} \\
\hline & \multicolumn{2}{|c|}{ Baik } & \multicolumn{2}{|c|}{ Cukup } & & & \\
\hline & $\mathbf{n}$ & $\%$ & $\mathbf{n}$ & $\%$ & $\mathbf{n}$ & $\%$ & \\
\hline Tinggi & 48 & 77.4 & 14 & 22.6 & 62 & 100 & \\
\hline Sedang & 3 & 33.3 & 6 & 66.7 & 9 & 100 & 0.012 \\
\hline Total & 51 & 71.8 & 20 & 28.2 & 71 & 100 & \\
\hline
\end{tabular}

Berdasarkan Tabel 12 dapat diketahui bahwa pekerja dengan efikasi tingkatan yang tinggi, memiliki perilaku penggunaan APD (Alat Pelindung Diri) yang cenderung baik. Hasil uji tabulasi silang menjelaskan terdapat hubungan yang signifikan antara efikasi tingkatan dengan perilaku penggunaan APD (Alat Pelindung Diri).

Sedangkan untuk data Tabulasi Silang Efikasi Keluasaan dengan Perilaku Penggunaan APD (Alat Pelindung Diri) di fungsi RSD (Receiving, Storage, Distribution) PT. Pertamina (DPPU) Juanda Sidoarjo dapat ditampilkan sebagaimana terlihat di Tabel 13.

Tabel 13. Tabulasi Silang Efikasi Keluasaan dengan Perilaku Penggunaan APD (Alat Pelindung Diri) di fungsi RSD (Receiving, Storage, Distribution) PT. Pertamina (DPPU) Juanda Sidoarjo 18 September 2019

\begin{tabular}{|c|c|c|c|c|c|c|c|}
\hline \multirow{3}{*}{$\begin{array}{l}\text { Efikasi } \\
\text { Keluasaan }\end{array}$} & \multicolumn{4}{|c|}{ Perilaku Penggunaan APD (Alat Pelindung Diri) } & \multirow{2}{*}{\multicolumn{2}{|c|}{ Persentase (\%) }} & \multirow{2}{*}{$\boldsymbol{P}$} \\
\hline & \multicolumn{2}{|c|}{ Baik } & \multicolumn{2}{|c|}{ Cukup } & & & \\
\hline & $\mathbf{n}$ & $\%$ & $\mathbf{n}$ & $\%$ & $\mathbf{n}$ & $\%$ & \multirow{4}{*}{0.017} \\
\hline Tinggi & 36 & 81.8 & 8 & 18.2 & 44 & 100 & \\
\hline Sedang & 15 & 55.6 & 12 & 44.4 & 27 & 100 & \\
\hline Total & 51 & 71.8 & 20 & 28.2 & 71 & 100 & \\
\hline
\end{tabular}

Berdasarkan Tabel 13 dapat diketahui bahwa pekerja dengan efikasi keluasaan yang tinggi, memiliki perilaku penggunaan APD (Alat Pelindung Diri) yang cenderung baik. Hasil uji tabulasi silang menjelaskan terdapat hubungan yang signifikan antara efikasi keluasaan dengan perilaku penggunaan APD (Alat Pelindung Diri).

Sedangkan untuk data Tabulasi Silang Efikasi Kekuatan dengan Perilaku Penggunaan APD (Alat Pelindung Diri) di fungsi RSD (Receiving, Storage, Distribution) PT. Pertamina (DPPU) Juanda Sidoarjo dapat ditampilkan sebagaimana terlihat di Tabel 14. 
Tabel 14. Tabulasi Silang Efikasi Kekuatan dengan Perilaku Penggunaan APD (Alat Pelindung Diri) di fungsi RSD (Receiving, Storage, Distribution) PT. Pertamina (DPPU) Juanda Sidoarjo 18 September 2019

\begin{tabular}{|c|c|c|c|c|c|c|c|}
\hline \multirow{3}{*}{$\begin{array}{l}\text { Efikasi } \\
\text { Kekuatan }\end{array}$} & \multicolumn{4}{|c|}{ Perilaku Penggunaan APD (Alat Pelindung Diri) } & \multirow{2}{*}{\multicolumn{2}{|c|}{ Persentase (\%) }} & \multirow{2}{*}{$\boldsymbol{P}$} \\
\hline & \multicolumn{2}{|c|}{ Baik } & \multicolumn{2}{|c|}{ Cukup } & & & \\
\hline & $\mathbf{n}$ & $\%$ & $\mathbf{n}$ & $\%$ & n & $\%$ & \multirow{4}{*}{0.710} \\
\hline Tinggi & 36 & 70.6 & 15 & 29.4 & 51 & 100 & \\
\hline Sedang & 15 & 75 & 5 & 25 & 20 & 100 & \\
\hline Total & 51 & 71.8 & 20 & 28.2 & 71 & 100 & \\
\hline
\end{tabular}

Berdasarkan Tabel 14 dapat diketahui bahwa pekerja dengan efikasi kekuatan yang tinggi, memiliki perilaku penggunaan APD (Alat Pelindung Diri) yang cenderung baik. Hasil uji tabulasi silang menjelaskan tidak terdapat hubungan yang bermakna antara efikasi kekuatan dengan perilaku penggunaan APD (Alat Pelindung Diri).

\section{Pembahasan}

Pekerja di fungsi RSD (recieving, storage, distribution) PT. Pertamina (Persero) DPPU Juanda ratarata berada di rentang umur 25-34 tahun. Hal ini menunjukkan bahwa mayoritas responden memiliki umur yang produktif untuk bekerja karena pada usia tersebut aktivitas fisik cenderung lebih berat dibanding usia lainnya. Kekuatan otot terbesar terjadi pada rentang umur 20-29 tahun. Seiring dengan berjalannya waktu, akan terjadi penurunan kekuatan otot yang berpengaruh dengan kinerja pekerja [10].

Tingkat pendidikan terakhir mayoritas pekerja di fungsi RSD (recieving, storage, distribution) PT. Pertamina DPPU Juanda adalah SMA. Berdasarkan Undang-Udang Republik Indonesia Nomr 20 Tahun 2003 tentang Sistem Pendidikan Nasional, pendidikan merupakan usaha sadar dan terencana untuk mewujudkan suasana belajar dan proses pembelajaran agar peserta didik secara aktif dapat mengembangkan potensi dirinya. Sehingga seorang yang berpendidikan akan mudah menerima informasi dan dapat berpengaruh dengan tindakan yang dilakukan.

Masa kerja mayoritas perusahaan ini di fungsi RSD (recieving, storage, distribution) memiliki masa kerja selama 6-10 tahun yaitu sebanyak 28 pekerja, pekerja dengan masa kerja $>10$ tahun sebanyak 26 pekerja, dan 17 pekerja dengan masa kerja $<6$ tahun, pekerja dengan umur maksimal adalah 54 tahun. Masa kerja merupakan sebuah ukuran waktu yang dapat diukur dengan lamanya jangka waktu seseorang bekerja pada suatu perusahaan [11]. Lamanya masa kerja seseorang dapat dilihat dari kepuasan yang dirasakan oleh pekerja, kejenuhan yang dirasakan, jabatan/jenjang karir yang sedang ditempati, dan tunjangan/kompensasi yang diterima sebagai hasil kerja.

Pengetahuan merupakan hasil tahu yang terjadi setelah melakukan pengindraan yang dimiliki (telinga, mata, hidung, rasa, dan raba). Pekerja di fungsi RSD (recieving, storage, distribution) PT. Pertamina (Persero) DPPU Juanda mayoritas memiliki pengetahuan yang tinggi, baik dari pendidikan terakhir SMA maupun D3/D4/Sarjana. Pemberian informasi akan meningkatkan pengetahuan seseorang sehingga seseorang memiliki kesadaran dalam melakukan tindakan, termasuk juga dalam terjadinya sebuah perilaku. Terjadinya sebuah perilaku yang dilandasi pengetahuan, kesadaran, dan sikap positif akan membentuk perilaku yang aman karena dilakukan atas dasar kemauan sendiri dan dalam keadaan sadar [12].

Dukungan emosional merupakan dukungan yang diberikan disekitar (keluarga, rekan kerja, dan perusahaan) kepada kita berupa empati, perhatian, nasihat, dan peringatan dalam suatu masalah yang sedang kita hadapi. Dengan mendapatkan dukungan emosional seseorang akan merasa nyaman dan tenteram, sehingga mereka akan cenderung berperilaku berdasarkan apa yang dikatakan orang sekitar [13]. Pekerja di fungsi RSD (recieving, storage, distribution) PT. Pertamina (Persero) DPPU Juanda mayoritas menerima dukungan emosional tinggi sebanyak 58 pekerja, sedangkan pekerja yang menerima dukungan emosional sedang berjumlah 13.

Dukungan informatif merupakan dukungan dengan memberikan tindakan-tindakan yang harus dilakukan dalam mengatasi masalah. Tindakan - tindakan dapat berupa informasi lewat lisan ataupun melalui media. Seseorang mendapatkan informasi baru akan menambah pengetahuannya dalam masalah yang sedang dihadapi, sehingga seseorang dapat merubah perilaku dalam mengatasi masalah yang sedang dihadapi [13]. Pekerja di fungsi RSD (recieving, storage, distribution) PT. Pertamina (Persero) DPPU Juanda mayoritas menerima dukungan informatif tinggi sebanyak 44 pekerja, sedangkan pekerja yang menerima dukungan informatif sedang sejumlah 27.

Dukungan instrumental merupakan dukungan berupa bantuan secara fisik maupun jasa kepada sesoerang untuk mengatasi masalah yang sedang dihadapi. Membantu orang lain secara langsung akan meringankan beban dalam menghadapi masalah, terlebih lagi masalah yang dihadapi adalah perilaku. Dengan adanya bantuan secara langsung maupun nyata membuat stres dan masalah yang dihadapi berkurang dan mengatasi masalah [13]. Pekerja perusahaan migas ini khususnya di fungsi RSD (recieving, storage, distribution) mayoritas menerima dukungan instrumental tinggi sebanyak 27 pekerja, sedangkan 
pekerja yang menerima dukungan instrumental sedang sejumlah 44 pekerja.

Dukungan penghargaan merupakan dukungan berupa pemberian apresiasi dari apa yang sudah dikerjakan, baik menghadapi masalah, dan kepatuhan berperilaku. Pekerja di fungsi RSD (recieving, storage, distribution) PT. Pertamina (Persero) DPPU Juanda mayoritas menerima dukungan penghargaan tinggi sebanyak 29 pekerja, pekerja yang menerima dukungan instrumental sedang sejumlah 26 pekerja, dan pekerja dengan dukungan penghargaan rendah 19 pekerja. Dukungan penghargaan merupakan bentuk apresiasi yang bisa diberikan baik dari keluarga, rekan kerja maupun perusahaan. Dampak yang ditimbulkan dari adanya penghargaan yaitu semakin termotivasi untuk melakukan tindakan - tindakan dalam mengatasi masalah maupun berperilaku [13].

Efikasi tingkatan merupakan bentuk keyakinan dan kemampuan diri dalam mengatasi masalah atau sikap dalam berperilaku dilihat dari tingkat hambatan yang sedang dihadapi [14]. Pekerja dengan keyakinan individu yang tinggi akan mampu menyelesaikan masalah dalam berperilaku dengan melihat kesulitan hambatan yang akan diterima , yaitu dengan melakukan tindakan - tindakan yang sesuai dengan tingkat hambatan. Mayoritas pekerja di fungsi RSD memiliki keyakinan untuk berperilaku sesuai dengan masalah yang sedang hadapi. Pekerja di fungsi yang sama di PT. Pertamina (Persero) DPPU Juanda mayoritas memiliki efikasi tingkatan yang tinggi sebanyak 62 pekerja, sedangkan pekerja memiliki efikasi tingkatan sedang sejumlah 9 pekerja.

Efikasi keluasaan merupakan bentuk keyakinan dan kemampuan diri dalam mengatasi masalah atau sikap dalam berperilaku berdasarkan keluasaan seseorang dalam menyelesaikan masalah. Sesorang dengan keleluasaan diri tinggi mampu beradaptasi di berbagai aktivitas sehingga masalah yang dapat tidak terjadi [14]. Pekerja dengan keyakinan individu yang tinggi akan mampu menyelesaikan masalah dalam berperilaku dengan melihat kesulitan hambatan yang akan diterima, yaitu dengan melakukan tindakan - tindakan yang sesuai dengan tingkat hambatan. Mayoritas pekerja di fungsi RSD memiliki keyakinan untuk berperilaku sesuai dengan masalah yang sedang hadapi, berbagai jenis kegiatan diperlukan keyakinan pekerja untuk dapat melakukan aktivitas dengan benar dan sesuai dengan prosesdur. Pekerja di fungsi RSD (recieving, storage, distribution) PT. Pertamina (Persero) DPPU Juanda mayoritas memiliki efikasi keluasaan yang tinggi sebanyak 44 pekerja, sedangkan pekerja memiliki efikasi tingkatan sedang sesebanyak 27 pekerja.

Efikasi kekuatan mayoritas pada pekerja di fungsi RSD (recieving, storage, distribution) PT. Pertamina (Persero) DPPU Juanda memiliki efikasi kekuatan yang tinggi yaitu sebanyak 51 pekerja, sedangkan pekerja memiliki efikasi tingkatan sedang sesebanyak 20 pekerja. Efikasi kekuatan merupakan bentuk keyakinan dan kemampuan diri dalam mengatasi masalah atau sikap dalam berperilaku berdasarkan ketahanan seseorang dalam berperilaku. Seseorang dengan kekuatan diri tinggi mampu mempertahankan diri dalam perilaku terntentu [14].

Perilaku merupakan respon individu terhadap suatu stimulus atau tindakan yang diamati serta memiliki frekuensi tertentu, durasi, dan tujuan yang baik atau tidak [15]. Pekerja di fungsi RSD (recieving, storage, distribution) PT. Pertamina (Persero) DPPU Juanda mayoritas memiliki perilaku penggunaan APD (Alat Pelindung Diri) yang tinggi sebanyak 51 pekerja, sedangkan pekerja memiliki perilaku penggunaan APD (Alat Pelindung Diri) yang sedang sebanyak 20 pekerja. Perilaku penggunaan APD (Alat Pelindung Diri) merupakan respon individu terhadap tindakan yang dilakukan pada suatu kondisi dan durasi tertentu dengan menggunakan alat pelindung di sebagian/seluruh tubuh yang bertujuan untuk mengurangi terjadinya kecelakaan kerja dampak kecelakaan kerja. Perilaku penggunaan APD (Alat Pelindung Diri) berjalan dengan baik. Hal ini dibuktikan dengan hasil observasi pada pekerja bahwa mayoritas pekerja sudah menggunakan APD (Alat Pelindung Diri) sebelum melaksanakan kegiatan. Namun masih terdapat beberapa pekerja yang belum melaksanakan SOP (Standart Operationa Procedure) dalam menggunakan APD (Alat Pelindung Diri), seperti tali strap pada helm yang belum digunakan, tidak menggunakan sarung tangan, tidak menggunakan kacamata UV (Ultra Violet), dan tidak menggunakan peredam suara (earplug/earmuff). Perusahaan sebenarnya sudah memberikan fasilitas kepada pekerja berupa pengecekan kondisi dan pergantian APD (Alat Pelindung Diri) apabila tidak layak digunakan. Namun kurangnya pelaporan mengenai kondisi APD (Alat Pelindung Diri) yang ada menjadi salah satu faktor masih adanya pekerja yang belum lengkap dalam menggunakan APD (Alat Pelindung Diri).

Umur bukan menjadi salah satu faktor yang berkaitan erat dengan perilaku penggunaan APD. Berdasarkan hasil penelitian, pekerja dengan rentang umur 25-34 tahun memiliki jumlah pekerja dengan perilaku penggunaan APD (Alat Pelindung Diri) yang tinggi terbanyak, sedangkan pekerja dengan rentang umur 35-44 tahun memiliki jumlah pekerja dengan perilaku penggunaan APD (Alat Pelindung Diri) sedang paling banyak. Hal ini selaras dengan penelitian mengenai kepatuhan penggunaan alat pelindung diri pada pekerja rekanan PT. Indonesia UP semarang menjelaskan bahwa tidak ada hubungan antara umur pekerja dengan kepatuhan penggunaan APD (Alat Pelindung Diri) dengan nilai $p=0,00$. Umur merupakan salah satu faktor yang berkaitan dengan terjadinya perubahan perilaku, namun banyak faktor lain yang dapat menghambat perubahan perilaku, misalnya masa kerja yang dapat menimbulkan kejenuhan [16]. Hal ini didukung dengan hasil observasi dan wawancara yang dilakukan kepada beberapa pekerja dengan umur di atas 35 tahun. Mereka berpendapat bahwa perilaku penggunaan APD (Alat 
Pelindung Diri) yang dilakukan sudah benar, karena dari awal mereka bekerja sampai sekarang tidak ada kecelakaan pada pekerja. Selain itu mereka tidak mematuhi seluruh APD (Alat Pelindung Diri) yang diperintahkan karena APD (Alat Pelindung Diri) yang diberikan tidak nyaman dipakai.

Latar belakang pendidikan pekerja bukanlah faktor utama yang bisa dikaitkan dengan kepatuhan penggunaan APD (Alat Pelindung Diri) pada pekerja. Berdasarkan hasil penelitian, mayoritas pekerja dengan pendidikan terakhir SMA memiliki perilaku penggunaan APD (Alat Pelindung Diri) tinggi. Setengah dari jumlah pekerja dengan pendidikan terakhir Sarjana memiliki perilaku penggunaan APD (Alat Pelindung Diri) yang sedang. Terjadinya perilaku penggunaan APD (Alat Pelindung Diri) pada pekerja pada dasarnya bukan hanya mengikuti peraturan yang diterapkan di perusahaan. Namun pemahaman tentang bahaya yang bisa terjadi di lingkungan kerja. Pemahaman tersebut dapat dilakukan oleh setiap pekerja dan tidak melihat pendidkan terakhir dari setiap pekerja. Hasil yang didapatkan juga mendukung bahwa baik lulusan SMA maupun Sarjana masih ada yang belum patuh dalam perilaku penggunaan APD (Alat Pelindung Diri). Hal ini selaras dengan penelitian [16] bahwa tidak ada hubungan antara pendidikan dengan kepatuhan penggunaan APD (Alat Pelindung Diri) pada pekerja di perusahaan rekanan PT. Indonesia Up Semarang. Pekerja memiliki pola pikir mengenai perilaku penggunaan APD (Alat Pelindung Diri) di lingkungan kerja yang dapat dilakukan oleh seluruh pekerja baik dari lulusan SMA maupun Sarjana.

Masa kerja bukan menjadi salah satu faktor yang berkaitan dengan perilaku penggunaan APD (Alat Pelindung Diri). Berdasarkan hasil penelitian, mayoritas pekerja dengan masa kerja 6-10 tahun memiliki perilaku penggunaan APD (Alat Pelindung Diri) yang tinggi sebanyak 22 pekerja dan perilaku penggunana APD (Alat Pelindung Diri) sedang sebanyak 6. Pekerja dengan masa kerja lebih dari 10 tahun memiliki perilaku penggunaan APD (Alat Pelindung Diri) tinggi 17 pekerja dan perilaku penggunaan APD (Alat Pelindung Diri) sedang 9 pekerja. Sedangkan pekerja dengan masa kerja $<6$ tahun memiliki perilaku penggunaan APD (Alat Pelindung Diri) tinggi sebanyak 12 pekerja dan memiliki perilaku penggunaan APD (Alat Pelindung Diri) sedang sebanyak 5 pekerja. Berdasarkan hasil penelitian baik pekerja yang baru bekerja dengan pekerja yang sudah lama bekerja tidak memiliki perbedaan perilaku yang signifikan dan presentase yang hampir sama besar. Hal ini selaras dengan penelitian oleh [16] bahwa hasil penelitian diperoleh $\mathrm{p}=0.638$ atau $\mathrm{H}_{0}$ tidak diterima. Peneliti menjelaskan bahwa dalam penelitiannya masa kerja bukan menjadi salah satu faktor yang berkatian dengan perilaku penggunaan APD (Alat Pelindung Diri), dikarenakan pekerja dengan masa kerja yang lama menimbulkan rasa kebosanan dalam bekerja, sehingga timbul ketidakpatuhan pekerja dalam berperilaku, salah satu diantaranya adalah perilaku penggunaan APD (Alat Pelindung Diri).

Pengetahuan merupakan salah satu faktor yang dapat dikaitkan dengan perilaku penggunaan APD (Alat Pelindung Diri). Berdasarkan hasil penelitian, mayoritas pekerja dengan pengetahuan tinggi memiliki perilaku penggunaan APD (Alat Pelindung Diri) yang tinggi sebanyak 48 pekerja dan pekerja dengan perilaku penggunaan APD (Alat Pelindung Diri) sedang sebanyak 11 pekerja. Sedangkan pekerja dengan pengetahuan sedang dengan perilaku penggunaan APD (Alat Pelindung Diri) tinggi sebanyak 3 pekerja dan pekerja dengan perilaku penggunaan APD (Alat Pelindung Diri) sedang sebanyak 9 pekerja. Pekerja yang mendapat pengetahuan menimbulkan persepsi terhadap objek yang dikenalkan. Sehingga membentuk sikap yang menjadi dorongan terhadap terjadinya perilaku. Hal ini selaras dengan penelitian yang dilakukan oleh [16] yang menjelaskan bahwa terdapat hubungan antara pengetahuan dengan perilaku penggunaan APD (Alat Pelindung Diri) pada pekerja. Pengetahuan yang diterima oleh pekerja akan meningkatkan motivasi yang kuat sehingga menimbulkan kesadaran untuk bertindak/berperilaku sesuai dengan peraturan atas dasar pengetahuan yang dimiliki.

Dukungan emosional dapat menjadi salah satu faktor yang berkaitan dengan perilaku penggunaan APD (Alat Pelindung Diri). Berdasarkan hasil penelitian, mayoritas pekerja yang menerima dukungan emosional tinggi memiliki perilaku penggunaan APD (Alat Pelindung Diri) yang tinggi sebanyak 46 pekerja dan pekerja dengan perilaku penggunaan APD (Alat Pelindung Diri) sedang sebanyak 12 pekerja. Sedangkan pekerja yang menerima dukungan emosional sedang dengan perilaku penggunaan APD (Alat Pelindung Diri) tinggi sebanyak 5 pekerja dan pekerja dengan perilaku penggunaan APD (Alat Pelindung Diri) sedang sebanyak 8 pekerja. Dukungan emosional dapat menjadi salah satu faktor yang berkaitan dengan perilaku penggunaan APD (Alat Pelindung Diri) karena dengan adanya perhatian, nasihat, dan pengawasan pada pekerja. Sehingga dapat menimbulkan sikap yang positif karena merasa diakui keberadaannya dan merasa dihargai. Hal ini selaras dengan penelitian yang dilakukan oleh [16] menjelaskan bahwa dengan adanya perhatian yang diberikan rekan kerja dan perusahaan kepada pekerja dan memjadikan rekan kerja sebagai contoh, mengakibatkan pengaruh kepada pekerja untuk mengikuti perilaku rekan kerjanya.

Dukungan informatif menjadi salah satu faktor yang berkaitan dengan perilaku penggunaan APD (Alat Pelindung Diri). Berdasarkan hasil penelitian, mayoritas pekerja yang menerima dukungan informatif tinggi memiliki perilaku penggunaan APD (Alat Pelindung Diri) yang tinggi sebanyak 41 pekerja dan pekerja dengan perilaku penggunaan APD (Alat Pelindung Diri) sedang sebanyak 3 pekerja. Sedangkan pekerja yang menerima dukungan informatif sedang dengan perilaku penggunaan APD (Alat 
Pelindung Diri) tinggi sebanyak 10 pekerja dan pekerja dengan perilaku penggunaan APD (Alat Pelindung Diri) sedang sebanyak 17 pekerja. Dengan adanya informasi mengenai perilaku penggunaan APD (Alat Pelindung Diri) baik secara lisan maupun menggunakan media, akan menyebabkan bertambahnya pengetahuan mengenai perilaku penggunaan APD (Alat Pelindung Diri) bagi pekerja. Sehingga dengan bertambahnya informasi yang menjadikan pengetahuan yang baru, akan menambah sikap yang positif yang berujung dengan perilaku penggunaan APD (Alat Pelindung Diri) yang benar. Hal ini selaras dengan penelitian yang dilakukan oleh [17] menjelaskan bahwa terdapat hubungan antara dukungan informatif dengan perilaku penggunaan APD (Alat Pelindung Diri) pada pekerja. Dengan adanya pemberian informasi dari perusahaan baik dalam bentuk toolbox meeting dan anjuran penggunaan APD (Alat Pelindung Diri) dengan poster kepada pekerja menimbulkan perilaku penggunaan APD (Alat Pelindung Diri) yang patuh.

Dukungan instrumental bisa menjadi salah satu faktor terjadinya sebuah perilaku penggunaan APD (Alat Pelindung Diri). Berdasarkan hasil penelitian, mayoritas pekerja yang menerima dukungan instrumental tinggi memiliki perilaku penggunaan ang tinggi sebanyak 23 pekerja dan pekerja dengan perilaku penggunaan APD (Alat Pelindung Diri) sedang sebanyak 4 pekerja. Sedangkan pekerja yang menerima dukungan instrumental sedang dengan perilaku penggunaan APD (Alat Pelindung Diri) tinggi sebanyak 28 pekerja dan pekerja dengan perilaku penggunaan APD (Alat Pelindung Diri) sedang sebanyak 16 pekerja. Dukungan instrumental berupa jasa maupun fisik seperti membantu membersihkan, menyiapkan, jasa untuk mengganti APD (Alat Pelindung Diri) yang tidak layak bisa menjadi salah satu faktor terjadi sebuah perilaku penggunaan APD (Alat Pelindung Diri). Karena dengan adanya bantuan langsung/tidak langsung berkaitan dengan masalah yang sedang dihadapi, seseorang akan menimbulkan sikap yang positif untuk berperilaku sesuai dengan peraturan yang telah ditetapkan. Hal ini selaras dengan penelitan yang dilakukan oleh [18] menjelaskan bahwa dukungan instrumental berupa pemenuhan fasilitas berupa pemberian APD (Alat Pelindung Diri) dan penggantian APD (Alat Pelindung Diri) ketika tidak layak digunakan merupakan salah satu faktor yang dapat mempengaruhi pekerja dalam perilaku penggunaan APD (Alat Pelindung Diri).

Dukungan penghargaan bukan menjadi salah satu faktor yang berkaitan dengan perilaku penggunaan APD (Alat Pelindung Diri). Berdasarkan hasil penelitian, mayoritas pekerja yang menerima dukungan penghargaan tinggi memiliki perilaku penggunaan APD (Alat Pelindung Diri) yang tinggi sebanyak 24 pekerja dan pekerja dengan perilaku penggunaan APD (Alat Pelindung Diri) sedang sebanyak 5 pekerja. Sedangkan pekerja yang menerima dukungan penghargaan sedang dengan perilaku penggunaan APD (Alat Pelindung Diri) tinggi sebanyak 18 pekerja dan pekerja dengan perilaku penggunaan APD (Alat Pelindung Diri) sedang sebanyak 8 pekerja. Sedangkan pekerja yang menerima dukungan penghargaan rendah yang memiliki perilaku penggunaan APD (Alat Pelindung Diri) tinggi sebanyak 9 dan pekerja dengan perilaku penggunaan APD (Alat Pelindung Diri) yang sedang sebanyak 7 pekerja. Dukungan penghargaan merupakan dukungan dengan memberikan pujian, apresiasi, dan penghargaan kepada pekerja yang telah melakukan perilaku penggunaan APD (Alat Pelindung Diri) dengan patuh. Namun dukungan tersebut bukan menjadi salah satu faktor yang berkaitan dengan perilaku penggunaan APD (Alat Pelindung Diri) pada pekerja. Hal ini dikarenakan pekerja tidak menjadikan penghargaan yang didapatkan dari perusahaan menjadi sesuatu yang penting, dan terkesan diacuhkan. Hal ini tidak sejalan dengan penelitian yang dilakukan oleh [19] menjelaskan bahwa pujian dan penghargaan yang diberikan oleh perusahaan kepada pekerja dapat mendorong pekerja dalam pembentukan perilaku penggunaan APD (Alat Pelindung Diri).

Efikasi tingkatan merupakan keyakinan pekerja bahwa patuh menggunakan APD (Alat Pelindung Diri). Berdasarkan hasil penelitian, mayoritas pekerja yang memiliki efikasi tingkatan tinggi memiliki perilaku penggunaan APD (Alat Pelindung Diri) yang tinggi sebanyak 48 pekerja dan pekerja dengan perilaku penggunaan APD (Alat Pelindung Diri) sedang sebanyak 11 pekerja. Sedangkan pekerja dengan pengetahuan sedang dengan perilaku penggunaan APD (Alat Pelindung Diri) tinggi sebanyak 3 pekerja dan pekerja dengan perilaku penggunaan APD (Alat Pelindung Diri) sedang sebanyak 9 pekerja. Efikasi tingkatan merupakan keyakinan pekerja bahwa patuh menggunakan APD (Alat Pelindung Diri) di setiap pekerjaan dengan tingkat bahaya yang dihadapi, pekerja tahu APD (Alat Pelindung Diri) seperti apa yang harus dilakukan sebelum melakukan kegiatan di fungsi RSD (recieving, storage, distribution). Hal ini selaras dengan penelitian yang dilakukan oleh [20] yang menjelaskan bahwa dengan adanya keyakinan dan komitmen pada pekerja bahwa setiap jenis kegiatan memerlukan APD (Alat Pelindung Diri) yang berbeda, dapat terbentuk suatu perilaku penggunaan APD (Alat Pelindung Diri) yang patuh.

Efikasi keluasaan merupakan keyakinan dan kemampuan diri pekerja untuk menggunakan APD (Alat Pelindung Diri) dalam kondisi apapun. Berdasarkan hasil penelitian, mayoritas pekerja yang menerima dukungan emosional tinggi memiliki perilaku penggunaan APD (Alat Pelindung Diri) yang tinggi sebanyak 48 pekerja dan pekerja dengan perilaku penggunaan APD (Alat Pelindung Diri) sedang sebanyak 11 pekerja. Sedangkan pekerja dengan pengetahuan sedang dengan perilaku penggunaan APD (Alat Pelindung Diri) tinggi sebanyak 3 pekerja dan pekerja dengan perilaku penggunaan APD (Alat Pelindung Diri) sedang sebanyak 9 pekerja. Dengan adanya keluasaan pekerja dalam menggunakan APD 
(Alat Pelindung Diri), pekerja akan merasa tidak terbebani untuk menggunakan APD (Alat Pelindung Diri) karena sudah memiliki keyakinan diri bahwa penggunaan APD (Alat Pelindung Diri) pada saat melakukan kegiatan di fungsi RSD (recieving, storage, distribution) merupakan hal wajib. Hal ini selaras dengan penelitian yang dilakukan oleh [20] yang menjelaskan bahwa dengan adanya sikap keluasaan pada pekerja mengenai perilaku penggunaan APD (Alat Pelindung Diri) yang taat. Akan memdorong pekerja untuk membentuk sebuah perilaku kesehatan yaitu perilaku penggunaan APD (Alat Pelindung Diri). Namun apabila pekerja tidak memiliki sikap keluasaan dapat mengakibatkan sebuah ancaman karena mendapat tekanan untuk menggunakan APD (Alat Pelindung Diri) yang berujung pada stress yang diterima.

Efikasi kekuatan merupakan kuat niat dan keyakinan kita dalam mewujudkan perilaku penggunaan APD (Alat Pelindung Diri). Berdasarkan hasil penelitian, mayoritas pekerja yang menerima dukungan emosional tinggi memiliki perilaku penggunaan APD (Alat Pelindung Diri) yang tinggi sebanyak 48 pekerja dan pekerja dengan perilaku penggunaan APD (Alat Pelindung Diri) sedang sebanyak 11 pekerja. Sedangkan pekerja dengan pengetahuan sedang dengan perilaku penggunaan APD (Alat Pelindung Diri) tinggi sebanyak 3 pekerja dan pekerja dengan perilaku penggunaan APD (Alat Pelindung Diri) sedang sebanyak 9 pekerja. Memang benar efikasi kekuatan merupakan kuat niat dan keyakinan kita dalam mewujudkan perilaku penggunaan APD (Alat Pelindung Diri). Namun tingginya niat dan keyakinan pekerja dalam perilaku penggunaan APD (Alat Pelindung Diri) bukan menjadi salah satu faktor yang berkaitan. Hal ini terjadi karena pekerja dengan keyakinan tinggi dan berkeyakinan rendah hanya berusaha patuh dalam peraturan dan merasa diawasi sikapnya oleh perusahaan. Seharusnya dengan keyakinan yang tinggi diimbangi dengan kesadaran berperilaku penggunaan APD (Alat Pelindung Diri) tanpa adanya paksaan dari perusahaan. Hal ini tidak sejalan dengan penelitian yang dilakukan oleh [20] yang menjelaskan bahwa niat dan komitmen yang tinggi membentuk perilaku pekerja untuk membentuk perilaku kesehatan.

\section{Simpulan dan Saran}

Berdasarkan hasil penelitian yang dilakukan oleh peneliti di fungsi RSD (recieving, storage, distribution) PT. Pertamina (Persero) DPPU Juanda, Sidoarjo diketahui bahwa sebagian besar pekerja di fungsi RSD (recieving, storage, distribution) PT. Pertamina (Persero) DPPU Juanda berada pada rentang usia 25-34 tahun, pekerja telah bekerja lebih dari 6 tahun, memiliki pendidikan terakhir di jenjang SMA, memiliki pengetahuan penggunaan APD (Alat Pelindung Diri) yang baik. Diketahui dari beberapa variabel karakteristik responden yang memiliki hubungan dengan perilaku penggunaan APD (Alat Pelindung Diri) adalah pengetahuan responden, dukungan emosional, dukungan informatif, dan dukungan instrumental memiliki hubungan dengan perilaku penggunaan APD (Alat Pelindung Diri), sedangkan dukungan penghargaan tidak ada hubungan. Efikasi tingkatan dan efikasi keluasaan juga memiliki hubungan dengan perilaku pekerja dalam penggunaan APD (Alat Pelindung Diri), sedangkan efikasi kekuatan tidak ada hubungan. Selain itu pengetahuan yang didukung dengan informasi juga memiliki pengaruh terhadap perilaku penggunaan APD (Alat Pelindung Diri). Saran yang dapat dilakukan yaitu mengadakan sosialisasi dan pembekalan informasi untuk perilaku penggunaan APD terbaru, melakukan pengawasan, melakukan pengecekan berkala pada kondisi kelayakan APD (Alat Pelindung Diri), serta menyediakan dam memelihara APD (Alat Pelindung Diri) secara rutin dan berkala.

\section{Ucapan Terima Kasih}

Penulis menyampaikan terimakasih kepada pihak PT. Pertamina (Persero) DPPU Juanda Sidoarjo yang telah mendukung dan memberikan kesempatan untuk menyelesaikan proses penelitian. Tidak lupa juga ucapan terimakasih ditujukan untuk Fakultas Kesehatan Masyarakat Universitas Airlangga yang telah memfasilitasi agar penelitian ini dapat terwujud

\section{Daftar Pustaka}

1. ILO, 2018. Safety and Health at Work. [Online] Available at: https://www.ilo.org/global/topics/safety-and-health-at-work/lang en/index.htm [Diakses 23 Mei 2019].

2. Kamar, I. F. M. \& Ahmad, Asmalia Che., 2016. A Conceptual Framework of Safety and Health in Construction Management. MATEC Web of Conferences, 66, p. 9

3. Marlina, L., \& Rizal, R., 2016. Penerapan SMK3 di Lingkungan Kerja Manufaktur Produk Makanan dan Minuman. Bina Teknika, 12(1), pp. 1-10

4. Saragih, V. I., Kurniawan, B. \& Ekawati, 2016. Analsisis Kepatuhan Pekerja Terhadap Penggunaan Alat Pelindung Diri (APD). Jurnal Kesehatan Masyarakat, 4(4).

5. Moniaga, F. and Rompis, V. (2019) Analisa Sistem Manajemen Kesehatan Dan Keselamatan Kerja (Smk3) Proyek Konstruksi Menggunakan Metode Hazard Identification And Risk Assessment, Jurnal Ilmiah Realtech, 15(2), pp. 65-73.. 
6. Saputro, Vondra Anggi (2015) Hubungan Antara Pengetahuan Dan Sikap Dengan Penggunaan Alat Pelindung Diri (Apd) Pada Pekerja Di Unit Kerja Produksi Pengecoran Logam. Skripsi Thesis, Universitas Muhammadiyah Surakarta.

7. Ismi Fauziah, (2019) Hubungan Antara Unsafe Act Dan Unsafe Condition Dengan Kecelakaan Kerja Pada Pekerja Di Bagian Produksi Pt. Perkasa Adiguna Sembada Tahun 2019. Skripsi thesis, Universitas Pembangunan Nasional Veteran Jakarta.

8. Sovira, Bella \& Nurjanah, 2015. Perilaku Tidak aman (Unsafe Behaviour) pada Pekerja di Unit Material PT. Sango Ceramics Indonesia Semarang. Visikes Jurnal Kesehatan, 14(2), pp. 109-114.

9. Harnida, Hana, 2015. Hubungan Efikasi Diri dan Dukungan Sosial dengan Burnout Perawat. Jurnal Psikologi Indonesia, 4(1), pp.31-43.

10. Sari, Erna N., Handayani, Lina. \& Saufi, Azidanti, 2017. Hubungan Antara Umur dan Masa Kerja dengan Keluhan Musculoskeletal Disorders (MSDs) pada Pekerja Laundry. Jurnal Kedokteran dan Kesehatan, 13(2), pp. 183-193.

11. Manabung, A.R., Suoth, L.F., \& Warouw, Finny, 2018. Hubungan Antara Masa Kerja Dan Beban Kerja Dengan Stres Kerja Pada Tenaga Kerja Di Pt. Pertamina Tbbm Bitung. Jurnal Kesehatan Masyarakat Universitas Sam Ratulangi, 7(5).

12. Gunawan, Indra. \& Mudayana, A. A., 2016. Hubungan Antara Pengetahuan, Sikap Dan Motivasi Dengan Perilaku Penggunaan Alat Pelindung Diri Pada Pekerja Bagian Produksi Pt.Katingan Indah Utama, Kabupaten Kotawaringin Timur, Provinsi Kalimantan Tengah. Unnes Journal of Public Health, 5(4), pp. 336-347.

13. Lambert, E. G., Minor, K. I., Wells, J. B., \& Hogan, N. L. (2016). Social support's relationship to correctional staff job stress, job involvement, job satisfaction, and organizational commitment. The Social Science Journal, 53(1), 22-32.

14. Husnawati, R., 2016. Hubungan Efikasi Diri Dan Iklim Organisasi Terhadap Kinerja Staf Tenaga Kependidikan Universitas Muhammadiyah Surakarta. Thesis. Surakarta: Fakultas Psikologi Program Magister Psikologi Profesi Universitas Muhammadiyah Surakarta.

15. Wawan, A. \& Dewi, M., 2010`. Teori dan Pengukuran, Sikap, dan Perilaku Manusia. Yogyakarta: Nuha Medika.

16. Puji, A. D., Kurniawan, B. \& Jayanti, S., 2017. Faktor Faktor Yang Berhubungan Dengan Kepatuhan Penggunaan Alat Pelindung Diri Pada Pekerja Rekanan (PT.X) di PT Indonesia Power Up Semarang. Jurnal Kesehatan Masyarakat, 5(5), pp. 20-31.

17. Aprinta, N., Cahyo, K., and Indraswari, R., 2017. Faktor - Faktor Yang Berhubungan Dengan Perilaku Penggunaan Alat Pelindung Diri (Apd) Pada Karyawan Pabrik Rokok Praoe Lajar Di Semarang. Jurnal Kesehatan Masyarakat (e-Journal), 5(5), pp. 1054 - 1062.

18. Program Studi D4 Keselamatan dan Kesehatan Kerja FK UNS, 2017. Prosiding Seminar Nasional Hasil-Hasil Penelitian dan Pengabdian Bidang K3 2017. In Khotijah et al., eds. Seminar Nasional Hasil-Hasil Penelitian dan Pengabdian Bidang K3 2017. Surakarta, 2017. UNS Press.

19. Dewi, F. C., Nugraha, P. \& Widjasena, B., 2017. Faktor - Faktor Yang Berhubungan Dengan Perilaku Pekerja Dalam Penggunaan APD di Sentra Pengasapan Ikan Kelurahan Bandarharjo Kota Semarang. Jurnal Kesehatan Masyarakat, 5(5), pp. 1000-1009.

20. Puspitasari, Y. R., BM, S. \& Cahyo, K., 2019. Beberapa Faktor yang Berpengaruh Terhadap Perilaku Kerja Aman (Safety Behavior) Petani Tembakau di Kabupaten Temanggung. Jurnal Kesehatan Masyarakat, 7(1), pp. 545-553. 